\title{
Protein Unc-119 Homolog A
}

National Cancer Institute

\section{Source}

National Cancer Institute. Protein Unc-119 Homolog A. NCI Thesaurus. Code C102482.

Protein unc-119 homolog A (240 aa, $27 \mathrm{kDa}$ ) is encoded by the human UNC119 gene.

This protein plays a role in subcellular protein localization. 